We sometimes wonder whether there is not too much standardisation in apparatus for elementary teaching. Instrument-makers are, of course, a necessity for specialised and accurate instruments, but it might be better if schools and colleges depended more on their own workshops.

The work already accomplished in Australia, and indeed also in Canada, shows that the movement towards research methods in industry is going on all over the Empire, and it is encouraging to know that the necessary co-operation, without too much centralisation, is being arranged between the councils operating abroad and the Advisory Council at work in London. Sufficient organising machinery would seem to have been provided both at home and in Australia and Canada. The supply of trained workers is the important matter, and that brings us back to our educational systems. Will the universities be able to give the necessary care to research to enable them to meet the demand for trained investigators that we hope to see in the near future? If they are to do so larger staffs will be necessary, and there must be less school-work in the universities. There are few university professors who do not spend a large portion of their time teaching school-work. Higher entrance examinations would remedy this evil, but the university is not always so rich that it can ignore the question of students' fees.

In connection with the establishment of this Federal research scheme in Australia, it is interesting to turn to the report of the British Science Guild adopted at the annual meeting on July $r$, x9I5, and to find that so early as January, I9I4, the South Australian branch of the Guild had drawn up plans for a Federal Institute for Original Research which were to be brought before a conference of the Australian Premiers. The institute proposed by the Guild was designed to give special attention to agriculture, and to undertake "research work beyond experimental farming." The Guild realised the importance of studying from a research point of view everything underlying the successful use of the land, including the wellbeing in every respect of the people engaged in farming operations. The list of subjects mentioned above, which the executive committee deals with in its report, shows that agriculture in all its bearings is receiving attention, and in this respect the idea of the South Australian branch of the British Science Guild has certainly borne fruit.

It would be well for us to consider in this country whether our agricultural research deals sufficiently with matters "beyond experimental farming." Experimental farming in its narrower sense can only lead to improvements in detail. Research work of a more fundamental character is required in agriculture as in other industries. The schemes adopted since the beginning of the war provide for such research work in connection with our manufactures, but it is not sufficiently clear that we intend to give the necessary attention to fundamental research bearing on agricultural pursuits.

$$
\text { NO. 2460, VOL. 98] }
$$

THE ERADICATION OF SLEEPING SICKNESS FROM PRINCIPE. ${ }^{1}$

DRINCIPE is one of a group of four islands in the Gulf of Guinea. It is r7. kilometres long and ro kilometres wide, and is 200 kilometres distant from the mainland. The main export of the island is cacao; sugar-cane, coffee, and palm kernel being practically negligible. For the cultivation of the cacao crop labour has been imported in the past from the African mainland. In all probability among these labourers there would be cases of sleeping sickness. These in themselves would constitute no danger to the island population or to their uninfected fellow-labourers, but in Principe unfortunately the carrier tsetse-fly, Glossina palpalis, also existed, and sleeping sickness mortality became so great that the economic life of the island was gravely menaced. The annual mortality was about 200 in a population of 3800 (average), so that in twenty years the mortality would be in excess of the total population.

How and where the fly was first imported (if it were so) is a matter of conjecture, but it is thought that this occurred in 1825 with the importation of cattle and slaves, and though so far as we are aware there are no other records of the fly putting to sea, Fernando Po, 40 kilometres from the coast, is also fly-infested, whereas San Thomé, I 30 kilometres south-west of Principe, is free from fly and likewise from sleeping sickness. As regards the distribution of the fly in the island, it is practically identical with that of the wild pigs. Neither is found higher than 250 metres above sea-level. In the case of the pig this distribution is determined by that of the oil-palm, on the fruit of which the pigs feed; but how far it is a case of the fly following the pig, or the latter finding security in the haunts of the fly, is a matter of some doubt.

The section of the work dealing with the trypanosomes of various animals, pig, ox, mule, dog, is unfortunately incomplete. A dimorphic trypanosome-that is, one showing flagellar and aflagellar forms-was found in the ox, dog, and mule, but its identity is not established. It may be the dimorphic trypanosome common in cattle in Africa, T. ugandae (dimorphic form of T. brucei), or it may be $T$. gambiense, though cattle are not definitely established as hosts of this trypanosome of man. Whether, too, the human trypanosome of Principe is a special variety of $T$. gambiense must remain doubtful, as the fallacies of the biometric method of distinguishing trypanosomes introduced by Bruce and here adopted are so many that its usefulness is problematical. This book gives an account of the results obtained by the third mission dispatched to study sleeping sickness by the Portuguese Government, the first having set to work in $187 \mathrm{r}$. Knowledge of the subject has increased greatly since that time, when indeed the cause of the disease was unknown, but the last mission was so successful in the practical application of this knowledge that the disease,

1 "Sleeping Sicknecs. A Record of Four Years' War against It in the Island of Principe." By B. F. Eruto da Costa, J. F. Sant' Anna, A. C. dos Santos, and M. G. de Araujo Alvares. Translated by Lieut.-Col. J. A Baillière, Tindall and Cox London. rgr6. Price $7 s .6 d$. net. 
or, to be strictly accurate, the carrier of the lisease, has been stamped out in the island.

The methods used for getting rid of the fly comprised:- $(x)$ Clearing of vegetation, felling of forest, clearing of woodlands and secondary jungle growth, so as to admit light and air into the haunts of the shade-loving tsetse. (2) Drainage of swamps and clearing of the banks of streams. (3) Extermination of pigs, dogs, and cattle.

For the protection of those at work in the fly areas the Maldonado method of trapping the fly was adopted. The members of the fly brigade wore canvas, back and front, covered with a viscid preparation made in Reading. (It would appear to be composed, like fly-papers, largely of boiled linseed oil.) By this means at the beginning of the campaign as many as 500 flies could occasionally be caught by a single man in a day, and the average caught by the gang was about 17,000 a month in r9II, less than 6000 a month in I9I2, while in the first three months of 1914 only I4 flies were caught by 297 men, and in the last nine months of the year none.

The mission is to be congratulated on the success of its efforts.

J. W. W. S

\section{CLEMENT REID, F.R.S.}

THE death of Mr. Clement Reid on December Io is a severe loss alike to geological and to botanical science. Born on January 6,1853 , Reid joined the Geological Survey in 1874 , and began field-work in the south-west of England, but was soon transferred to the eastern counties. Here, in mapping the Cromer Forest Bed and other plant-bearing formations exposed on the coast, he entered upon the investigation of our Pliocene and Pleistocene flora, which thereafter he pursued with characteristic enthusiasm and ability throughout his life. Devising ingenious methods for separating out the seeds of plants from any material in which they lay hidden, he showed the significance of these inconspicuous fossils as indicators of past climate; and he soon became recognised as our leading authority on this subject. In the "Cromer" memoir of the Geological Survey (1882) he firmly established his capability both as an investigator and as an expositor. His next field-work was in Yorkshire, first on the north-eastern moorlands and then in the Holderness country, after which it was carried southward into Lincolnshire, the results being published in the "Holderness" memoir (1885). This done, he was sent to map the South Downs and the coastal tract of Sussex; and he worked westward thence through Hampshire and part of the Isle of Wight into Dorset and Wiltshire, describing this country in several more memoirs, published between 1898 and 1903. Meanwhile, he had also produced a collective "General" memoir on the Pliocene deposits of Britain (I890), during the preparation of which he visited Belgium and North Italy for the study of the equivalent deposits there.

Besides his official work, Reid had by this time NO. 2460 , VOL. 98] contributed many notable and widely discussed papers to scientific societies and periodicals, dealing mainly with the palæobotany of the later geological periods; with the climatal conditions indicated by geological formations; and with subjects in the debatable territory where geology and archæology meet. In I899 he summed up his knowledge of past botanical conditions in a book full of acute observation and suggestion, entitled "The Origin of the British Flora"; and, in I913, he dealt similarly, in a small book, with our "Submerged Forests." His critical study of the fossil Characeæ, in collaboration with Mr. J. Groves, of which the first-fruits are in course of publication, has now been lamentably arrested.

In his later researches Reid was ably assisted by his wife (previously Miss E. M. Wynne Edwards), joint-author with him in his description of the interesting Pliocene flora of Tegelen, Holland, and in several other botanical and geological papers.

On his advancement to the post of district geologist in I901, Reid was placed in charge of the Geological Survey work in Cornwall and Devon, and afterwards in the south-eastern district around London. On retiring from official duty early in I9I3, he went to live at a chosen spot at Milford-on-Sea, overlooking the Solent, and died there, after a short illness.

In recognition of his work, Reid was awarded by the Geological Society the Murchison Fund in I886, and the Bigsby Medal in 1897; and by the Royal Geological Society of Cornwall, the Bolitho Medal in r9ir. He was elected a fellow of the Royal Society in 1899 . He served terms of office on the council of the Linnean Society and of the Geological Society, being vice-president of the latter from I9I3 to I9I6. He leaves a widow, but no children.

\section{WILLIAM ELLIS, F.R.S.}

FOR the third time in about six months the Royal Meteorological Society has to mourn the loss of a past president. Mr. William Ellis was born at Greenwich on February 20, 1828, and succumbed to heart failure on December II at Blackheath, having spent nearly the whole of his long life in the immediate neighbourhood of the Royal Observatory. His father, Henry Ellis, was an assistant there, and he himself began work there as a boy computer in I841. After several years' experience as an astronomical observer, he left in $185^{2}$ to take charge of Durham Observatory, returning in 1853 when a vacancy occurred on the staff at Greenwich. He was attached to the Time Department, and soon afterwards had charge of it, including the galvanic batteries and circuits, but after eighteen years' superintendence of that work, and more than twenty years as a regular astronomical observer on the staff, he was transferred, on Glaisher's retirement, to the Magnetical and Meteorological Department, of which he was superintendent for nineteen years, until his retirement at the end of 1893 , in which year he 